\title{
Soil seed bank and the effect of needle litter layer on seedling emergence in a tropical pine plantation
}

\author{
Andrea Bueno \& Zdravko Baruch \\ Laboratorio de Ecología Vegetal. Departamento de Estudios Ambientales. Universidad Simón Bolívar. Aptdo 89000. \\ Caracas, Venezuela; abuenog@gmail.com, zbaruc@usb.ve
}

Received 03-IX-2010. C Corrected 01-II-2011. Accepted 01-III-2011.

\begin{abstract}
The soil seed bank is the basis for community establishment and permanence and plays a primary role in natural restoration of degraded or altered ecosystems. As part of a restoration project, this study aimed to quantify the soil seed bank and to evaluate the effect of the needle litter layer on seedling emergence. Soil samples from a pine plantation were collected at random in the field and set to germinate in a greenhouse. Half of them were covered by a $6 \mathrm{~cm}$ layer of dead pine needles simulating field conditions. In the field, $20 \times 20 \mathrm{~cm}$ plots were established, half were left intact and half were cleaned from the litter needles. All four treatments had 15 replicates and seedling emergence was recorded during six months. Soil seed bank density was $1222 / \mathrm{m}^{2}$ from 17 morphotypes. In the field, the number of morphotypes and seedlings was only $9 \%$ and $6 \%$ respectively, of those emerged in the greenhouse, possibly due to watering and lack of predation in the latter. In both cases, herbs and graminoids were the dominant emerging seedlings, making up to 70-90\% of the total. The needle layer didn't prevent seeds from reaching the soil but strongly reduced $(>50 \%)$ seedling emergence, although high variability within treatments resulted in no statistically significant differences. These results show that the needle layer hinders germination and/or emergence of seedlings from the seed bank. Its removal may be a recommended technique to accelerate natural restoration in pine plantations. Rev. Biol. Trop. 59 (3): 1071-1079. Epub 2011 September 01.
\end{abstract}

Key words: germination, pinus caribaea, restoration, seedlings, soil seed bank.

Viable seeds stored in the soil at a given time make up the soil seed bank, a source of propagules that contributes to the long term permanence of individual species, and the plant community as well, and to the processes of succession and restoration after disturbances (Harper 1977, Gurevitch et al. 2006, Csontos 2007). Soil seed bank studies are of great importance for the understanding of the secondary succession and it is considered as a necessary first step for the design of ecological restoration plans (Baskin \& Baskin 1998, Abella et al. 2007, Bossuyt \& Honnay 2008).

Several factors may induce or inhibit germination from the soil seed bank. The time that seeds remain in the soil seed bank is an attribute of individual species life history, and it is generally related to its growth form (Barbour et al. 1999). However, environmental variables, as well as the standing vegetation of a site, can induce or inhibit germination from the soil seed bank. For example, canopy species modify understory conditions in several ways, e.g.: by altering water and nutrient availability, by modifying microclimate, and by determining the quality of the litter layer that covers the soil (Grime 1979, Godefroid et al. 2006). This litter layer can prevent germination by altering the intensity and quality of sunlight reaching the soil, and by forming a mechanical barrier for the access of seeds to the soil and the emergence of seedlings (Facelli \& Pickett 1991). In some cases, it may also limit germination and establishment of seedlings due to allelophatic 
effects (Del Moral \& Cates 1971, Crawley 1986, Fernández et al. 2006, van Andel 2006). Conversely, this layer may favor recruitment by maintaining soil humidity and by hiding the seeds from predators. The interaction of these effects determines recruitment, and ultimately the structure of the plant community (Kanowski et al. 2003).

In conifer woods, it has been found that the needle layer can favour or inhibit germination of seeds from the seed bank (McAlpine \& Drake 2002, Sánchez et al. 2003). Despite the widely recognized importance of understanding soil seed bank characteristics, which include identifying potential factors enhancing or inhibiting recruitment of seeds, few studies have attempted to do so in the tropics. It has been suggested but not demonstrated, that low recruitment of woody species in the understory of tropical pine plantations is due to needle accumulation (Lugo 1992, Cavelier \& Santos 1999). The present study constitutes an attempt to address this question, as part of a pine plantation restoration project. Its objectives are: (i) to quantify the composition of the soil seed bank and its correspondence with the standing vegetation, as this would help elucidate the possible trajectory of succession, and (ii) to determine the effect of the needle layer on seedling emergence. Research was carried out in the field as well as in a greenhouse, which is often not done, in order to detect potential differences between both types of conditions. Our results may contribute to the selection of procedures for the natural restoration of tropical pine plantations.

\section{MATERIALS AND METHODS}

The plantation is located in the natural area of Universidad Simón Bolívar, Caracas, Venezuela $\left(10^{\circ} 24^{\prime} 36^{\prime \prime} \mathrm{N}-66^{\circ} 53^{\prime} 11^{\prime \prime} \mathrm{W}\right)$ at 1300 m.a.s.l. It extends on $\sim 50$ ha composed mainly by Caribbean Pine (Pinus caribaea Morelet). The plantation covers the slopes $(15-45 \%)$ that surround the campus and was established more than 35 years ago, as protection from erosion and landslides. Initial tree density was $\sim 1$ 360/ha (AGROFORCA 1990) with a canopy cover between $81-84 \%$. Average annual temperature is $19.9^{\circ} \mathrm{C}$ and rainfall is $944 \mathrm{~mm}$. Soils are sandy, acidic, shallow and unfertile. The plantation was never thinned and shows signs of senescence, therefore restoration efforts, in order to resemble a nearby native forest, are a priority.

Seed bank composition was determined with the seedling emergence method (Korb et al. 2005). In January 2008, 15 sampling points were selected at random along a transect in a representative area of the plantation. At each point, two $400 \mathrm{~cm}^{2}$ plots $(20 \times 20 \mathrm{~cm})$ were established: in one of them $(\mathrm{F}-\mathrm{N})$ all pine needles were carefully removed. The other $(\mathrm{F}+\mathrm{N})$ was left intact. In both, seedling emergence was monitored every two weeks for 6 months. In addition, at each point two sets of 15 soil samples were collected $(10 \mathrm{~cm}$ diameter $\mathrm{x} 5 \mathrm{~cm}$ depth) and brought to the greenhouse and placed on $20 \times 14 \times 4 \mathrm{~cm}$ trays. One set of trays was covered by a $6 \mathrm{~cm}$ deep layer of carefully washed and cleaned dead pine needles to remove any remaining seeds. This treatment $(\mathrm{Gh}+\mathrm{N})$ evaluated the effect of pine needles on emergence under controlled conditions. The second soil sample set was placed in similar trays, but left uncovered with needles. This treatment (Gh-N) evaluated composition and abundance of species in the soil seed bank. In addition, seeds obtained by cleaning and washing of the needles in the $\mathrm{Gh}+\mathrm{N}$ treatment were placed on sterile sand. This treatment ( $\mathrm{SN}$ ) evaluated composition and abundance of seeds retained by the needle layer.

Trays were placed in the greenhouse under a shading net to simulate conditions in the plantation understory, and their location in the greenhouse was randomized bi-weekly. Trays were watered regularly and seedling emergence was recorded daily during the first two weeks, and weekly during the next 6 months. To control possible contamination, nine trays with sterile soil were placed among the treatment trays and seedling emergence was recorded. Emerging seedlings were identified following Steyermark \& Huber (1978) and the ones that 
could not be recognized were grouped according to morphological characteristics, and labeled alphabetically as morphotypes.

Temperature, relative humidity and rainfall were recorded inside and outside of the plantation with loggers (Onset Hobo H08-032-08) and rain gauges. Depth and dry weight of the needle layer was measured at 15 random points. In the greenhouse, maximum and minimum temperatures (Taylor 5458 thermometer) and radiation (LI-COR LI-188 radiometer) were recorded. Understory vegetation was sampled in 15 circular plots $\left(2 \mathrm{~m}\right.$ radius; $12.67 \mathrm{~m}^{2}$ ) next to each seed bank sampling point. Species composition and density was recorded.

Density of each species or morphotype was obtained by adding the number of individuals that emerged in each tray and is presented on a square meter basis. Percentage frequency was also calculated. The Index of Value Importance (IVI) for each species was calculated by adding relative density and frequency. Shannon diversity $(\mathrm{H})$ and evenness $\left(\mathrm{E}_{\mathrm{H}}\right)$ were calculated for each treatment (Krebs 1989). The same calculations were made for understory vegetation. Similarity among treatments was determined with the quantitative Sørensen index (SS) (Mueller-Dombois \& Ellenberg 1974). The effect of pine needles on seedling emergence was evaluated using Permutational Multivariate Analysis of Variance, PERMANOVA (Anderson 2001), based on Bray-Curtis distances using the PRIMER software (Clarke et al., 2006). A Mantel test (Mantel 1967) was employed to compare the two matrices from the greenhouse treatments (Gh-N and Gh+N) (McCune \& Mefford 2001). Additionally, comparisons were made qualitatively by comparing IVI and species richness. Numerical correspondence between the soil seed bank and the standing vegetation was not calculated because not all morphotypes in the soil seed bank could be identified.

\section{RESULTS}

Environment: Mean maximum temperature was $\sim 4^{\circ} \mathrm{C}$ lower below the pines than outside (25.5 vs $29.3^{\circ} \mathrm{C}$, while mean minimum temperature was slightly higher (15.6 vs $15.5^{\circ} \mathrm{C}$ ) which resulted in mean minimum relative humidity higher inside the plantation than outside (41\% vs 28\%). Rainfall could not be measured from January to March, but these are dry months and in 2008 the rainy season started in April accumulating $418 \mathrm{~mm}$ until the end of July. Average depth of the needle layer on the soil was $14.5 \pm 4.3 \mathrm{~cm}$ which weighed $1728 \pm 590 \mathrm{~g} / \mathrm{m}^{2}$. Air temperature in the greenhouse was close to that in the field ranging between $15 \pm 2^{\circ} \mathrm{C}$ and $29 \pm 3^{\circ} \mathrm{C}$. Photosynthetically active radiation was $20.8 \% \pm 1.7 \%$ of that outside the greenhouse which was close to that recorded in the pine understory (16-19\%, unpublished data).

\section{Soil seed bank composition and the effect of needles}

Greenhouse: The potential maximum seed bank, represented by the (Gh-N) treatment, comprised 144 emerged seedlings from 17 morphotypes (Table 1), whose density was 1 $222 / \mathrm{m}^{2}$. There was a high variability among trays (number of seedlings ranged from 0 to 36 seedlings per tray) but Emilia coccinea and Melinis minutiflora were the most important species, representing $75 \%$ of the total of seedlings (Appendix). Only 23 seedlings from three morphotypes emerged from seeds retained in the needle layer (treatment SN) Table 1, where E. coccinea was also the absolute dominant (91\% of all seedlings) (Appendix). Contamination in the greenhouse was minimal. Only two morphotypes emerged from control trays which were excluded from the analysis.

The presence of the needle layer $(\mathrm{Gh}+\mathrm{N})$ decreased the number of seedlings by $>50 \%$, but the number of morphotypes decreased by only $8 \%$ resulting in increased diversity $(\mathrm{H})$ and evenness $\left(\mathrm{E}_{\mathrm{H}}\right)$ (Table 1). Here, E. coccinea and M. minutiflora were also dominant (53\% of emerged seedlings, Appendix). Due to high variability, (in some trays no seedlings emerged at all, but in others up to 12 seedlings emerged) the difference between treatments (Gh-N vs 
TABLE 1

Summary of seedling emergence (total number and density), diversity and evenness in all greenhouse and field treatments

$\begin{array}{ccccccc}\text { Treatment } & \text { Total seedlings } & \text { Seedlings } / \mathrm{m}^{2} & \text { Morphotype richness } & \mathrm{H} & \mathrm{E}_{\mathrm{H}} \\ \text { Gh-N } & 144 & 1222.3 & 17 & 1.67 & 0.58 \\ \text { Gh+N } & 69 & 585.7 & 14 & 2.11 & 0.78 \\ \text { SN } & 23 & 195.2 & 3 & .36 & 0.26 \\ \text { F-N } & 9 & 15.0 & 4 & .92 & 0.57 \\ \text { F+N } & 6 & 10.0 & 1 & - & - \\ \text { Stand. Veget. } & 287 & 22.8 & 31 & 2.01 & 0.60\end{array}$

Gh-N: Greenhouse treatment without needle layer, Gh+N: Greenhouse treatment with needle layer, SN: Seeds retained by the needles, F-N: Field treatment without needle layer, F+N: Field treatment with needle layer, Stand. Veget.: Standing vegetation. $\mathrm{H}$ : Shannon diversity index. $\mathrm{E}_{\mathrm{H}}$ : Shannon evenness.

$\mathrm{Gh}+\mathrm{N})$ was not statistically significant (PERMANOVA, $\mathrm{p}>0.05)$. The Mantel test $(\mathrm{r}=0.113$ and $\mathrm{p}=0.128$ ) which compared the $\mathrm{Gh}+\mathrm{N}$ and Gh-N treatments, showed that the matrices were similar.

Both treatments had 10 morphotypes in common with a Ss of $62.1 \%$. In all greenhouse treatments the emergence sequence was similar: first M. minutiflora, E. coccinea and dicot $\mathrm{E}$ and lastly Melastomataceae D and dicots I and $\mathrm{H}$. Only $16 \%$ of the seeds emerged from the soil seed bank were retained by the needles in treatment $\mathrm{SN}$ ).

\section{Field}

In the field, the number of morphotypes and seedlings, in $\mathrm{F}+\mathrm{N}$ and $\mathrm{F}-\mathrm{N}$ treatments, was only $9 \%$ and $6 \%$ respectively of those emerged in the greenhouse (Table 1). Similarity between field treatments was $37.7 \%$ with almost absolute predominance of M. minutiflora (Appendix). Again, differences between treatments were not significant (PERMANOVA, $\mathrm{p}>0.05$ ). The standing vegetation next to the sampling plots comprised 31 species, of which $52 \%$ were woody (Appendix). The dominant species were the graminoids Scleria sp. and Laciasis sp., while Melastomataceae was the dominant family (Appendix). Species richness was $45 \%$ higher than that of the seedlings emerged in the greenhouse $(\mathrm{Gh}-\mathrm{N})$, but $\mathrm{H}$ y $\mathrm{E}_{\mathrm{H}}$ were similar (Table 1).
Since it was impossible to identify all morphotypes, similarity between vegetation composition and seed bank could not be calculated. However, only $20 \%$ of the understory families were represented in the seed bank (five families), although they differ in importance (Appendix). E. coccinea, the dominant in the soil seed bank, was the fourth most important in the understory, while $M$. minutiflora, second in the seed bank, was the $13^{\text {th }}$ in the understory. Scleria sp., the dominant of the understory, appeared only twice in the seed bank (Appendix).

\section{DISCUSSION}

The soil seed bank was dominated by $E$. coccinea and $M$. minutiflora which produce numerous, light-weight and wind-dispersed seeds that characterize early-successional or ruderal species (Fenner \& Kitajima 1999, Gurevitch et al. 2006). Seed density $\left(1222 / \mathrm{m}^{2}\right)$ was within the wide range reported for pine plantations in temperate zones (Moles \& Drake 1999, Onaindia \& Amezaga 2000, Wang et al. 2009). Unfortunately, these figures are unavailable for tropical pine plantations. The high variability between replicates found here is frequent in this type of studies (Thompson 1986, Moles \& Drake 1999, Olano et al. 2002), and may suggest a non-random spatial distribution of seeds in the soil of the pine plantation. Despite 
the relatively favorable conditions under the pine canopy (lower air temperature and higher humidity) which would favor survival and growth of the seedlings, emergence was only $<10 \%$ of that in the greenhouse. This difference may have been caused by water limitation, as the field plots experienced an initial three month water shortage. In addition, it is also possible that herbivory might have reduced field germination and seedling survival.

The needle layer may retain seeds, which depends on their size and shape thus preventing seeds from reaching soil surface and germinate (Facelli \& Picket 1991). Here, the needle layer, despite being deep, did not prevent seeds from reaching the soil. In addition, this low retention did not have a differential effect since species composition found in the needles was the same as in the soil. In the greenhouse, pine needles decreased by $52 \%$ the total of seedling emerged from the soil. This reduction was more evident in E. coccinea and M. minutiflora although species richness was similar in both treatments. The high variability between replicates resulted in no statistically significant needle effect. Nevertheless, the identity of the emerged species was different. Four morphotypes in the $\mathrm{Gh}+\mathrm{N}$ treatment were exclusive while seven were exclusive for the Gh-N treatment. A differential effect of the litter layer on individual species has been reported in previous works (Guerrero \& Bustamante 2007, Navarro-Cano et al. 2010). In this study, this suggests that the qualitative effect of the needles was more important than the quantitative one. In the field, pine needles inhibited seedling emergence much less than in the greenhouse. This might have been caused by the already diminished emergence caused by field water stress and/or herbivory, although Abella \& Covington (2007) found that needle removal in a pine forest did not affect species composition of the community and, presumably, seedling emergence. The effect of the needle cover on recruitment could have been: (a) mechanical, by acting as a barrier to seedling emergence, (b) physiological, by limiting the quantity and/ or quality of radiation reaching the soil and affecting germination, or (c) biochemical, if there is an allelopathic effect of leachates from the pine needles, although washing the needles prior to the establishment of the greenhouse treatments to remove potential seeds may have diminished this effect. In this study the needle layer barrier appeared to be selective to some degree. Dzwonko \& Gawronski (2002) reported that small seeded species are most affected by the presence of needles, as they lack nutrient reserves to grow across the mechanical barrier imposed by the litter.

Some studies have shown that the litter layer may affect not only species recruitment in terms of richness and number of seedlings emerged, but it also may influence seedling performance in terms of shoot/root ratio, biomass, number of leaves, among others (Navarro-Cano et al. 2009, 2010). These variables were not considered in this study, but it would be important to include them in future researches, as they also indicate potential negative effects of the presence of the litter layer.

Since it was not possible to identify all seedlings emerged from the soil seed bank and some understory species, the correspondence between them was established only partially. Morphotype richness in the understory was higher than that of the seed bank, suggesting the importance of seed bank sampling throughout the year. However, it is also possible that limited time for germination allowed in this study underestimated the real composition of the seed bank. E. coccinea and M. minutiflora turned out to be less important in the understory that in the seed bank. It is possible that shading under the canopy inhibited their growth after emergence. On the other hand, Scleria sp., the most important species in the standing vegetation had a frequence of only $13 \%$ in the seed bank. This lack of correspondence has been found numerous times (Korb et al. 2005, Sakai et al. 2005, Hopfensperger 2007, Lang \& Halpern 2007, Zobel et al. 2007, Bossuyt \& Honnay 2008) and has been attributed to biological differences among species (seed viabilidad and/or likelihood to be predated) or to methodology (germination technique, time of 
sampling, number or volume of soil samples) which may limit quantification of the soil seed bank (Brown 1992, Malo 2000, Csontos 2007).

The results obtained here suggest that the needle layer in the pine plantation has a negative effect on the emergence of seedlings from the soil seed bank. Its removal may help enhance natural restoration in tropical pine plantations.

\section{RESUMEN}

El banco de semillas del suelo es la base para el establecimiento y la permanencia de una comunidad y desempeña un papel fundamental en la restauración natural de los ecosistemas degradados o alterados. Como parte de un proyecto de restauración, este estudio tuvo como objetivo cuantificar el banco de semillas del suelo y evaluar el efecto de la capa de hojarasca de pino sobre la emergencia de las plántulas. Las muestras de suelo de la plantación de pinos fueron recolectadas al azar en el campo y se pusieron a germinar en un invernadero. La mitad de ellas estaban cubiertas por una capa de $6 \mathrm{~cm}$ de hojarasca simulando condiciones de campo. En el campo se establecieron parcelas de $20 \times 20 \mathrm{~cm}$, la mitad se dejaron intactas y la otra mitad se limpiaron de la hojarasca. Para los cuatro tratamientos se realizaron 15 repeticiones y la emergencia de plántulas se registró durante seis meses. La densidad del banco de semillas del suelo fue de $1222 / \mathrm{m}^{2}$ de 17 morfotipos. En el campo, el número de morfotipos y plántulas fue sólo de $9 \%$ y $6 \%$ respectivamente, de los que emergieron en el invernadero, posiblemente debido al riego y la falta de depredación. En ambos casos las plántulas dominantes fueron las hierbas y gramíneas, alcanzando el 70-90\% del total. La capa de hojarasca no impidió que las semillas llegaran al suelo, pero se presentó una emergencia de plántulas muy reducida ( $>50 \%)$, debido a la alta variabilidad de los tratamientos no se produjeron diferencias estadísticamente significativas. Estos resultados muestran que la capa de hojarasca impide la germinación y/o la emergencia de las plántulas del banco de semillas del suelo. Su eliminación puede ser una técnica recomendada para acelerar la restauración natural en las plantaciones de pino.

Palabras clave: germinación, Pinus caribaea, restauración, plántulas, banco de semillas.

\section{REFERENCES}

Abella, S. \& W. Covington. 2007. Forest floor treatments in Arizona ponderosa pine restoration ecosystems: no short-term effects on plant communities. West. N. Am. Naturalist 67: 120-132.
Abella, S., J. Springer \& W. Covington. 2007. Seed banks of an Arizona Pinus ponderosa landscape: responses to environmental gradients and fire cues. Can. J. Forest Res. 37: 552-567.

AGROFORCA, Servicios Técnicos Agroforestales C.A. 1990. Informe técnico forestal para realizar un aclareo en el bosque de pino de la Universidad Simón Bolívar, Caracas, Estado Miranda, Venezuela.

Anderson, M.J. 2001. A new method for non-parametric multivariate analysis of variance. Austral Ecol. 26: $32-46$.

Barbour, M., J. Burk, W. Pitts, F. Gilliam \& M. Schwartz. 1999. Terrestrial plant ecology. Benjamin/Cummings. Menlo Park, California, USA.

Baskin, C. \& J. Baskin. 1998. Seeds: ecology, biogeography, and evolution of dormancy and germination. Academic, San Diego, California, USA.

Bossuyt, B. \& O. Honnay. 2008. Can the seed bank be used for ecological restoration? An overview of seed bank characteristics in European communities. J. Veg. Sci. 19: 875-884.

Brown, D. 1992. Estimating the composition of a forest seed bank: a comparison of the seed extraction and seedling emergence methods. Can. J. Botany 70: 1603-1612.

Clarke, K. \& R. Gorley. 2006. PRIMER v6: User Manual/ Tutorial. PRIMER-E, Plymouth, Devon, United Kingdom

Cavelier, J. \& C. Santos. 1999. Efectos de plantaciones abandonadas de especies exóticas y nativas sobre la regeneración natural de un bosque montano en Colombia. Rev. Biol. Trop. 47: 775-784.

Crawley, M. 1986. The structure of plant communities. In M. Crawley (ed). Plant ecology. Blackwell, London, United Kingdom.

Csontos, P. 2007. Seed banks: ecological definitions and sampling considerations. Community Ecol. 8: 75-85.

Del Moral, R. \& R.G. Cates. 1971. Allelopathic potential of the dominant vegetation of western Washington. Ecology 52: 1030-1037.

Dzwonko, Z. \& S. Gawronski. 2002. Influence of litter and weather on seedling recruitment in a mixed oak-pine woodland. Ann. Bot-London 90: 245-251.

Facelli, J. \& S. Pickett. 1991. Plant litter: its dynamics and effects on plant community structure. Bot. Rev. 57: 1-25. 
Fenner, M. \& K. Kitajima. 1999. Seed and seedling ecology. In F. Pugnaire \& F. Valladares (eds). Handbook of functional plant ecology. Marcel Dekker, New York, New York, USA.

Fernandez, C., B. Lelong, B. Vila, J.P. Mevy, C. Robles, S. Greff, S. Dupouyet \& A. Bousquet-Melou. 2006. Potential allelopathic effect of Pinus halepensis in the secondary succession: an experimental approach. Chemoecology 16:97-105.

Godefroid, S., S. Phartyal \& N. Koedam. 2006. Depth distribution and composition of seed banks under different tree layers in a managed temperate forest ecosystem. Acta Oecol. 29: 283-292.

Grime, J. 1979. Plant strategies and vegetation processes. John Wiley \& Sons, Chichester, West Sussex, United Kingdom.

Guerrero, P.C. \& R.O. Bustamante. 2007. Can native tree species regenerate in Pinus radiata plantations in Chile? Evidence from field and laboratory experiments. Forest Ecol. Manag. 253: 97-102.

Gurevitch, J., S. Schneiner \& G. Fox. 2006. The ecology of plants. Sinauer, Sunderland, Massachusetts, USA.

Harper, J. 1977. Population biology of plants. Academic, London, United Kingdom.

Hopfensperger, K. 2007. A review of similarity between seed bank and standing vegetation across ecosystems. Oikos 116: 1438-1448.

Kanowski, J., C. Catterall, G. Wardell-Johnson, H. Proctor \& T. Reis. 2003. Development of forest structure on cleared rainforest land in eastern Australia under different styles of reforestation. Forest Ecol. Manag. 183: 265-280.

Korb, J., J. Springer, S. Powers \& M. Moore. 2005. Soil seed banks in Pinus ponderosa forests in Arizona: Clues to site history and restoration potential. Appl. Veg. Sci. 8: 103-112.

Krebs, C. 1989. Ecological methodology. Harper Collin, New York, New York, USA.

Lang, N. \& C. Halpern. 2007. The soil seed bank of a montane meadow: consequences of conifer encroachment and implications for restoration. Can. J. Botany 85: 557-569.

Lugo, A. 1992. Comparison of tropical tree plantations with secondary forests of similar age. Ecol. Monogr. 62: $1-41$.
Malo, J. 2000. Hardseedness and the accuracy of seed banks estimates obtained through germination. Web Ecol. 1: 70-75.

Mantel, N. 1967. The detection of disease clustering and generalized regression approach. Cancer Research 27: 209-220.

McAlpine, K. \& D. Drake. 2002. The effects of small-scale environmental heterogeneity on seed germination in experimental treefall gaps in New Zealand. Plant. Ecol. 165: 207-215.

McCune, B. \& M.J. Mefford. 2001. PC-ORD. Multivariate analysis of ecological data, Version 4. MjM Software Design, Gleneden Beach, Oregon, USA.

Moles, A. \& D. Drake. 1999. Potential contributions of the seed rain and the seed bank to regeneration of native forest under plantation pine in New Zealand. New Zeal. J. Bot. 37: 83-93.

Mueller-Dombois, D. \& H. Ellenberg. 1974. Aims and methods of vegetation ecology. John Wiley and Sons, New York, New York, USA.

Navarro-Cano, J.A., G. Barbera \& V. Castillo. 2010. Pine litter from afforestations hinders the establishment of endemic plants in semiarid scrubby habitats of natura 2000 network. Rest. Ecol. 18:165-169.

Navarro-Cano, J.A., G.G. Barbera, A. Ruiz-Navarro \& V.M. Castillo. 2009. Pine plantation bands limit seedling recruitment of a perennial grass under semiarid conditions. J. Arid Environ.73: 120-126.

Olano, J., I. Caballero, N. Laskurain, J. Loidi \& A. Escudero. 2002. Seed bank special pattern in a temperate secondary forest. J. Veg. Sci. 13: 775-784.

Onaindia, M. \& I. Amezaga. 2000. Seasonal variation in the seed banks of native woodland and coniferous plantations in Northern Spain. Forest Ecol. Manag. 126: $163-172$.

Sakai, A., S. Sato, T. Sakai, S. Kuramoto \& R. Tabuchi. 2005. A soil seed bank in a mature conifer plantation and establishment of seedlings after clear-cutting in southwest Japan. J. Forest Res. 10: 295-304.

Sánchez, J., B. Muñoz \& L. Montejo. 2003. Efectos de tratamientos robustecedores de semillas sobre la germinación y establecimiento de árboles pioneros bajo condiciones de estrés. Ecotropicos 16: 91-112.

Steyermark, J. \& O. Huber. 1978. Flora del Ávila. Flora y vegetación de las montañas del Ávila, de la Silla y del 
Naiguatá. Sociedad Venezolana de Ciencias Naturales. Caracas, Estado Miranda, Venezuela.

Thompson, K. 1986. Small-scale heterogeneity in the seed bank of an acidic grassland. J. Ecol. 74: 733-738.

Van Andel, J. 2006. Species interactions structuring plant communities. In E. van der Maarel (ed). Vegetation ecology. Blackwell, Oxford, Oxfordshire, United Kingdom.
Wang, J., H. Ren, L. Yang, D. Li \& Q. Guo. 2009. Soil seed banks in four 22-year-old plantations in South China: Implications for restoration. Forest Ecol. Manag. 258: 2000-2006.

Zobel, M., R. Kalamees, K. Püssa, E. Roosaluste \& M. Moora. 2007. Soil seed bank and vegetation in mixed coniferous forest stands with different disturbance regimes. Forest Ecol. Manag. 250: 71-76.

\section{APPENDIX}

A. Total number of seedlings, density, frequence and Importance Value Index (IVI) are showed for the greenhouse treatments

\begin{tabular}{|c|c|c|c|c|c|c|c|c|c|c|c|c|}
\hline & \multicolumn{4}{|c|}{ Gh-N } & \multicolumn{4}{|c|}{ SN } & \multicolumn{4}{|c|}{$\mathrm{Gh}+\mathrm{N}$} \\
\hline & 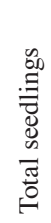 & 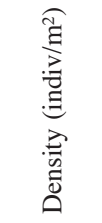 &  & $\sum$ & 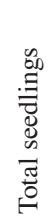 & 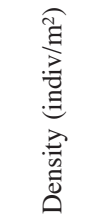 & 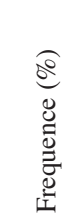 & $\sum$ & 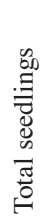 & 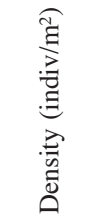 & 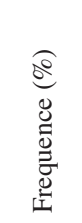 & $\sum$ \\
\hline Asteraceae. Emilia coccinea & 61 & 517.78 & 40.00 & 59.50 & 21 & 178.25 & 20.00 & 151.42 & 19 & 161.28 & 66.67 & 51.93 \\
\hline Poaceae. Melinis minutiflora & 48 & 407.44 & 26.67 & 44.76 & 1 & 8.49 & 6.67 & 24.35 & 18 & 152.79 & 33.33 & 38.28 \\
\hline $\mathrm{N}(\operatorname{dicot})$ & 8 & 67.91 & 20.00 & 14.13 & & & & & 1 & 8.49 & 6.67 & 3.89 \\
\hline$M($ dicot $)$ & 6 & 50.93 & 26.67 & 15.60 & & & & & & & & \\
\hline $\mathrm{O}$ (monocot) & 3 & 25.46 & 20.00 & 10.65 & & & & & & & & \\
\hline A Melastomataceae & 2 & 16.98 & 13.33 & 7.10 & & & & & & & & \\
\hline F Cecropia sp. & 2 & 16.98 & 13.33 & 7.10 & & & & & 2 & 16.98 & 6.67 & 5.34 \\
\hline D Melastomataceae & 2 & 16.98 & 13.33 & 7.10 & & & & & 4 & 33.95 & 26.67 & 15.55 \\
\hline E (dicotiledónea) & 1 & 8.49 & 6.67 & 3.55 & 1 & 8.49 & 6.67 & 24.35 & 3 & 25.46 & 20.00 & 11.66 \\
\hline G (dicotiledónea) & 1 & 8.49 & 6.67 & 3.55 & & & & & 2 & 16.98 & 13.33 & 7.78 \\
\hline H (dicotiledónea) & 1 & 8.49 & 6.67 & 3.55 & & & & & 7 & 59.42 & 26.67 & 19.90 \\
\hline I (dicotiledónea) & & & & & & & & & 5 & 42.44 & 33.33 & 19.44 \\
\hline Cyperaceae. Scleria sp. & & & & & & & & & 4 & 33.95 & 13.33 & 10.68 \\
\hline Poaceae. Laciasis sp. & & & & & & & & & 1 & 8.49 & 6.67 & 3.89 \\
\hline
\end{tabular}

Gh-N: Greenhouse treatment without needle layer, SN: Seeds retained by the needles, Gh+N: Greenhouse treatment with needle layer. 
B. Total number of seedlings, density, frequence and Importance Value Index (IVI) are showed for the field treatments

\begin{tabular}{|c|c|c|c|c|c|c|c|c|c|c|c|c|}
\hline & \multicolumn{4}{|c|}{$\mathrm{F}-\mathrm{N}$} & \multicolumn{4}{|c|}{$\mathrm{F}+\mathrm{N}$} & \multicolumn{4}{|c|}{ Standing vegetation } \\
\hline &  & 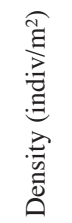 & 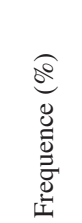 & 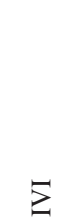 & 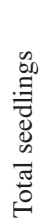 & 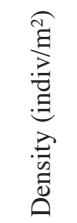 & 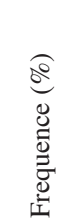 & $\sum$ & 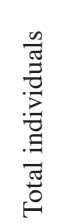 & 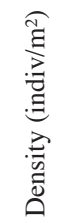 &  & $\sum$ \\
\hline Asteraceae. Emilia coccinea & 1 & 1.67 & 6.67 & 31.12 & & & & & 21 & 1.67 & 40.00 & 15.01 \\
\hline Poaceae. Melinis minutiflora & 5 & 8.33 & 6.67 & 75.56 & 6 & 10.00 & 6.67 & 200.00 & 3 & 0.24 & 6.67 & 2.33 \\
\hline Cyperaceae. Scleria sp. & & & & & & & & & 121 & 9.63 & 86.67 & 58.83 \\
\hline Poaceae. Laciasis sp. & 1 & 1.67 & 6.67 & 31.12 & & & & & 43 & 3.42 & 40.00 & 22.68 \\
\hline R (dicotiledónea) & 2 & 3.33 & 13.33 & 62.20 & & & & & & & & \\
\hline Fern & & & & & & & & & 22 & 1.75 & 13.33 & 10.23 \\
\hline Clusiaceae. Clusia sp. & & & & & & & & & 16 & 1.27 & 53.33 & 15.83 \\
\hline Orchidaceae. Epidendrum sp. & & & & & & & & & 11 & 0.88 & 20.00 & 7.68 \\
\hline Melastomataceae. Miconia albicans & & & & & & & & & 6 & 0.48 & 20.00 & 5.94 \\
\hline Myrsinaceae. Rapanea sp. & & & & & & & & & 6 & 0.48 & 26.67 & 7.22 \\
\hline Rubiaceae. Psychotria sp. & & & & & & & & & 6 & 0.48 & 20.00 & 5.94 \\
\hline Clusiaceae. Clusia sp. & & & & & & & & & 5 & 0.40 & 26.67 & 6.87 \\
\hline Fabaceae. Senna sp. & & & & & & & & & 4 & 0.32 & 26.67 & 6.52 \\
\hline Melastomataceae & & & & & & & & & 4 & 0.32 & 26.67 & 6.52 \\
\hline
\end{tabular}

Only species with IVI $\geq 3$ are displayed. Only species with IVI $\geq 3$ are displayed.

F-N: Field treatment without needle layer, F+N: Field treatment with needle layer. 